\title{
Lazzarato's 'political entrepreneur' revisited: the case of Noko Jeans
}

\author{
Karl Palmås*
}

\begin{abstract}
This article revisits Maurizio Lazzarato's 1994 text on the 'strategies of the political entrepreneur' in the context of Noko Jeans, a recent Sweden-based venture to produce jeans in North Korea, while simultaneously influencing the political regime in the country. After a brief introduction to the venture in question, the article reviews Lazzarato's discussion on political entrepreneurship, which interrogates how such entrepreneurial action concurrently generates consumer interest and political discussion, thus blurring the boundary between business and politics. The article then discusses Lazzarato's theoretical points in light of the empirical case of Noko Jeans, first on an analytical level, then in relation to a recent event in which the founders were interviewed. The review thus aims at a re-evaluation of Lazzarato's work, suggesting that his conceptualisation of political entrepreneurship may prove useful when describing phenomena such as Noko Jeans.
\end{abstract}

Keywords: Political entrepreneurship, Social entrepreneurship, North Korea, Maurizio Lazzarato

\section{Review}

'Trade opens the world that the left closed'. This is the concluding sentence in a 2009 op-ed article in the Swedish conservative broadsheet Svenska Dagbladet, applauding a new entrepreneurial venture called Noko Jeans (Gudmundsson 2009). This brand, the article explains, is the brainchild of three young advertising professionals, who one day decided to e-mail North Korea and ended up producing jeans in the country. Documentation from this adventure is easily accessed by typing the brand name into your nearest search engine; there is ample 'social media' coverage of the entrepreneurs' travels and encounters. Can this initiative, the entrepreneurs ask, help us get to know the North Koreans a bit better?

Economic collaboration with dictatorships is a politically sensitive topic, at least in those cases where the regime in question is negligible, in terms of economic importance. Therefore, it is hardly surprising that the North Korea entrepreneurs have been widely covered in the media: New York Times, Washington Post, The Guardian and BBC News have all contributed to the spread of the Noko story. The above-mentioned Swedish broadsheet states that the initiative is to be evaluated as a trade-off: On the

Correspondence: karl.palmas@chalmers.se

Management of Organizational Renewal and Entrepreneurship Chalmers University of Technology, Gothenburg SE-412 96, Sweden one hand, trade may open a dictatorship; on the other hand, there is a risk that the economic activity buttresses the regime. There is also a trade-off to be made in relation to labour conditions: The entrepreneurs propose that their involvement in the country can strengthen the rights of workers, whereas Swedish union leaders warn that such rights are difficult to monitor in a closed country like North Korea.

These debates are, in themselves, hardly novel. However, the interesting thing here is that political discussion serves to fuel a product launch. Something has happened when it is the op-ed page, not the business pages or the glossy weekend lifestyle magazines, that spread the word about new entrepreneurial ventures. The point is not so much that the media has been fooled by shrewd marketers, but that this (legitimate) political discussion has generated consumer interest in a new product. Are we, in light of an increasingly globalised entrepreneurship, likely to see more of these political controversies?

As far as one can ascertain from the media coverage, the Noko entrepreneurs are no strangers to such controversy. In December 2009, the fashionable Stockholm department store PUB chose to shut down their Noko section. 'This is a political campaign that PUB does not want to be associated with', the management explained.

\section{实}

(c) 2012 Palmås; licensee Springer. This is an Open Access article distributed under the terms of the Creative Commons Attribution License (http://creativecommons.org/licenses/by/2.0), which permits unrestricted use, distribution, and reproduction in any medium, provided the original work is properly cited. 
However, the department store closed the shop the night before to its official opening, just after a popular release party. From a publicity point of view, this was nevertheless a highly fortunate series of events. The association with politics is effective even when it is denied; indeed, it even tickles our interest even more when it is. Explicit or implicit, confirming or denying, the reference to politics seems to stir up consumer passions.

Two years after the above-mentioned article, Noko Jeans terminated its operations. Still, though the entrepreneurial endeavour failed to survive, it raises interesting questions. In this venture, we find a type of entrepreneurship that taps into our capacity to become politically involved; the entrepreneurs manage to mobilise interest among citizens, who may be compelled to buy the product. It is difficult, and maybe unproductive, to try to disassociate the initiative's 'message' from its business operations: they are inseparable. In other words, the separation of business and politics that underpins modern economic theory has imploded. Remember Milton Friedman's point that 'the kind of economic organisation that provides economic freedom directly, namely, competitive capitalism, also promotes political freedom because it separates economic power from political power and in this way enables the one to offset the other' (Friedman 1962).

\section{Lazzarato's political entrepreneur}

During the heyday of the late 1990s IT-bubble, some 'new economy' observers welcomed the imminent implosion of politics and business. In the future, they said, activism will appear in the guise of entrepreneurship. However, this same prospect was also discussed in a more nuanced manner. In an article originally published in Italian in 1994, sociologist Maurizio Lazzarato presents a term that may prove useful when analysing ventures like Noko Jeans: 'political entrepreneur' (Lazzarato 2007).

His exemple of this phenomenon is Benetton - one of the companies lauded by the new economy observers (Wieners 1996). In the text, which was republished in English in 2007, Lazzarato describes the Italian fashion retailer as a company that does not simply operate within the economic sphere, but is also active in politics and the moulding of opinion. This, he suggests, signifies the emergence of a new political-economic formation, in which the production of goods and the production of political discussion have become the same thing.

The notion of 'political entrepreneurship' has a long history in the social sciences (Weber 1970; Schumpeter 1943; Krugman 1994), but Lazzarato's usage of it is particularly interesting when trying to understand phenomena such as Noko Jeans. In his 1994 text, he points out the contradiction that the term entails: As hinted in the above- mentioned Friedman quote, the classical liberal model of the economy posits that entrepreneurship entails following a market-mediated economic self-interest, which in turn precludes political motivations. However, Lazzarato also notes that this separation is also fundamental for the Habermasian social theory that still prevailed during the 1990s: "The definition of the "political entrepreneur" has a specific polemical value since economic theory and official politics are based precisely on the separation between the economic and the political. Analogously, in fashionable philosophies, this separation is defined as the separation between "instrumental rationality" and "communicative rationality" (Lazzarato 2007).

Thus, we can no longer understand contemporary society along the lines of a problematic in which the instrumental rationality of 'the system' colonises the communicative rationality of 'the lifeworld', as posited by Habermas $(1984,1987)$. The advent of political entrepreneurs such as Benetton is a sign that the production of goods has started to resonate with the production of citizens' worldviews and the production of a public sphere of political deliberation. It is not so much a case of commodity production colonising the other two forms of production; instead, the three production processes are mutually dependent. The communication that produces meaning for citizens is not to be relegated to a role of merely 'legitimating' certain business practices; value itself is to be understood in terms of such communication.

Lazzarato thus holds Benetton to be emblematic for a new economic formation, in which companies own neither factories nor workers. Rather, they orchestrate a federation of autonomous production facilities. Companies do not even own the distribution network, which is managed through franchise deals with independent stores. Production and distribution are thus managed without direct ownership or disciplinary control. The capacity to control this empire is related to the brandrelated magnetism of the corporate entities. The federation-and-franchising strategy is sustainable for as long as a company can maintain its allure, thus securing production for the federation of factories and consumers for the franchisees.

Benetton thus secures the 'social construction of the market' (Lazzarato 2007), through the production of worldviews for citizens. It must create a 'world' that individuals can step into and feel at home in. So, while Benetton does not own production facilities or distribution channels, it nevertheless creates all its advertising in-house. Publicity, Lazzarato points out, is construed as a factor of production. In the case of Noko Jeans, publicity around the product generated a new public sphere. Benetton was a pioneer in this instance: The company is well-known for the ad campaigns that it ran in the 80 s and 90 s, dealing 
with issues such as HIV/Aids, migration and the death penalty. Similarly, the company established the magazine colors, which dealt with similar themes.

To sum up, Lazzarato's term 'political entrepreneur' signifies a venture that generates political deliberation on the back of the entrepreneur's market-based manoeuvres. Such political entrepreneurs thus relate to the outside world as consisting of 'citizen-consumers' (Lazzarato 2007) that partake in a politico-cultural public sphere and simultaneously act as consumers of commodities.

\section{Noko jeans as a political entrepreneur}

At this point, we may return to the case of Noko Jeans, which in many ways appears to be a miniature Benetton. The Swedish initiative was never meant to acquire a factory but rather to mobilise one at arms length, by the securing of a flow of production. Indeed, under pressure by the American trade embargo, the North Korean factory managers were happy to collaborate with the Swedes (Larsson 2010). As hinted above, the entrepreneurs never meant to own a store but rather work with other outlets. Moreover, it is tempting to compare Benetton's publicity focus with that of the three Swedish advertising professionals.

Still, the most striking parallel between the two cases is the two-pronged generation of controversy and political deliberation, on the one hand, and consumer desires, on the other. In the end, the initiative, not least the actions of the department store PUB, ended up highlighting the hypocrisy of Western consumerism. As one Swedish op-ed writer pointed out, a substantial share of the consumer goods purchased by Western consumers are produced in single-party states. The rich countries often referred to as democracies are hardly stringent in their trade relationships with the so-called dictatorships and autocracies; realpolitik tends to rule the day.

Are there, however, aspects of the Noko Jeans venture that can lead us towards a qualification of Lazzarato's claims? The original text is titled 'Strategies of the political entrepreneur', which suggests that political entrepreneurs are aware of this new economic formation, consciously strategising around the management of 'citizen-consumers'. Could the same thing can be said about Noko Jeans? Indeed, by the looks of things, the venture appears to be a well-coordinated publicity campaign, coupled with a suitably daring business plan.

This proposition was explored further at a public seminar arranged at the University of Gothenburg on 14 October 2011, during which the author interviewed the founders of Noko Jeans. To what extent do such entrepreneurs reflect upon the implosion of business and politics, entrepreneurship and activism? Jakob Ohlsson, one of three co-founders, says that the Noko Jeans initiative was somewhat agnostic to the above-mentioned divide between doing business and doing politics. Ohlsson continues:

JO: We wanted to make money, we wanted to change North Korea, we wanted to create a discussion about the clothing industry in general - and it was fun, obviously. We had a lot of trouble finding a language for the project, because it is a serious thing, North Korea has concentration camps, many of the things that go on there are just awful, but at the same time, we wanted to create something more positive to show that you can change some small things.

Did the entrepreneurs follow a deliberate strategy? Ohlsson replies that the venture started off in a modest fashion, as 'an email prank call', and adds:

JO: We did not have a business strategy, no strategy for anything, we just wanted to see if we could get a reply.

Thus, at the outset, the venture followed an ad hoc mode of organising, though more elaborate plans were added later on. Still, the conversation with the company founders suggests that the unfolding of the story of Noko Jeans cannot be explained with reference to deliberate strategies. Rather, the plot seems to be driven by the actors that surrounded the venture - journalists, diplomats, corporate managers, fashion editors, potential consumers and so forth. So, the PUB department store debacle was not a planned publicity stunt?

JO: I wish it was planned! Our long-term goal was to build a self-sustainable company that could sell jeans, and by selling jeans, we can go to North Korea and maintain a relationship with the people there. You can't just go there; you need to have a reason: 'I am going to North Korea, and the reason I am going to North Korea is to produce jeans' - then it is ok. Our initial media strategy was to try to get this into the fashion world, because that is how you sell things.

Tor Rauden Källstigen, another member of the founding trio, continues:

TRK: ... and nobody responded, it was completely silent.

Instead, the initiative got sucked into the world of oped pages and political deliberation. Ohlsson describes how the first article in the conservative newspaper took the initiative in a new direction:

JO: Since Svenska Dagbladet was the first paper to write about it, I think a lot of people interpreted it as 
a free market ideology project, selling the idea that free markets is going to solve every problem in the world. As a company, we would have liked to be in a fashion context; in that case, we would have been able to sell the product, and continue with the project. The political context is more narrow. In the end, the only ones who bought the jeans were journalists, politicians, people from the foreign ministry and a lot of American Koreans. This was all based on the initial interpretation of the project.

So, here we have an email prank call that evolves into an entity that hopes to establish itself as a self-sustainable company. This company, in turn, is meant to fund and act like a front organisation for ongoing relations with North Korea. However, it fails to attract the interest of the fashion scene and instead ends up fuelling political debates. One Swedish commentator has likened it to an art project. Would the founders agree?

TRK: I think it is an interesting question, because if we would have done it only as an art project, then we would not have gotten to [the department store] PUB, and there would not have been this crazy [political] discussion.

JO: Yes, but I think [Noko Jeans] suffered from that as well because some people thought it was just a gimmick that we just wanted to do this one thing, a public relations spectacle and nothing else. And of course, we wanted a PR spectacle, because we wanted attention and because we wanted to sell jeans. But if we could skip the PR spectacle and still sell the jeans, thus maintaining the relationship with the North Koreans, I think we would have rather done that.

The case of Noko Jeans therefore suggests that there are 'political entrepreneurs' that match Lazzarato's description but does not operate through conscious strategies. In order to do business and to maintain the North Korea relationship, publicity must be created. However, these processes are difficult to master, and in this way, the fate of the enterprise seems to have been sealed by reactions of the outside world. Thus, in the words of Mintzberg et al. (1998), political entrepreneurs are not necessarily 'volutaristically' controlling the world; there can also be a fair amount of 'determinism' inherent in the unfolding of the entrepreneurial endeavour.

\section{Success in political entrepreneurship}

What are, then, the determinants for being a successful political entrepreneur? In a text published 10 years after the above-mentioned article, Lazzarato (2004) continues to discuss how contemporary enterprises mobilise citizen-consumers, constructing a market before the production of the product. Thus, consumption is no longer about using a good, in the sense of depleting it, but rather about becoming a part of a world that the company has created for the consumer. In this way, the role of entrepreneurs has increasingly become to create lifestyles which strike a chord among the citizens-consumers.

This also mean that the citizen-consumer is enrolled in the sphere that the company generates, becoming subject to a incessant tests and modulations. This implies that the consumer contributes to the creative process. This aspect of entrepreneurship has intensified since the late 1990s, as companies increasingly try to draw users closer in the R\&D process (von Hippel 2005) and use social media and analytics software to get to know their prospective consumers better. (Palmås 2011) Most notably, the lean startup movement draws heavily on such tools (Ries 2011).

On a basic level, Noko Jeans could be seen as a part of this development. Through blogs and other social media, citizen-consumers could easily become a part of the Noko endeavour and thus provide various forms of webbased feedback. However, do the Swedish entrepreneurs feel that they have been successful in producing a 'world' for their prospective consumers? And have they managed to bring them into the creative process? Ohlsson replies that this aspect of the enterprise was more prominent in the early phases of the venture. When initially blogging about the idea to produce jeans in North Korea, 'people were so interested, they so wanted this', but this interest waned as the actual products were created. In this way, the entrepreneurs failed to capitalise on this initial interest. Still, judging by the media coverage, the Noko Jeans appears to be successful venture. Do the entrepreneurs consider it a success?

TRK: It depends on what parameters you are looking at. Business-wise, not so good. Some people related to the project have said: 'Have you ever seen a project that failed so much getting this much of an aura, or feeling of success?' We totally failed in the distribution because the fashion industry did not want us to the extent that we first thought. Ideaswise or politics-wise, I think it was a success, but at the same time, I would have really liked to see the project go on, to keep producing, keep the contact and work more long-term.

Thus, during the early stages of the project, the founders had managed to construct a world for the citizenconsumers that they imagined would buy the jeans. Nevertheless, after the product launch approached, it was evident that the entrepreneurs had not succeeded in 
creating a market. By having 'simply' created a space for political deliberation, the venture failed to become economically sustainable.

\section{Conclusions}

In an increasingly borderless economy, entrepreneurial ventures may end up short-circuiting different political regimes and thus cause political controversy. Some entrepreneurs may even seek such controversy, hoping to raise political awareness and produce social change. In this context, Maurizio Lazzarato's work on 'political entrepreneurship' may assist scholars in conceptualising such ventures. However, empirical case studies can add to Lazzarato's account. When examining political entrepreneurs such as Noko Jeans, it is evident that such ventures are not always volutaristically controlled. Instead, they may well be determined by the outside forces. Such contingencies may also cause entrepreneurs to fail when trying to convert the passions of citizen-consumers into markets and revenues.

\section{Competing interests}

The author declares that he has no competing interests.

\section{Acknowledgments}

The author wishes to thank Jakob Ohlsson and Tor Rauden Källstigen for agreeing to be interviewed at the University of Gothenburg seminar. The research has been carried out under the auspices of the Swedish Knowledge Foundation's research programme on 'Societal entrepreneurship'. The author also wishes to thank the Chalmers University of Technology Library for the reimbursement of the article processing charge.

Received: 12 March 2012 Accepted: 8 August 2012

Published: 8 August 2012

\section{References}

Friedman, M (1962). Capitalism and Freedom. Chicago, IL: University of Chicago Press. Gudmundsson, P (2009). En hälsning från de svenska jeansarbetarna. Svenska Dagbladet: En hälsning från de svenska jeansarbetarna.

Habermas, J (1984). The Theory of Communicative Action, Vol I. Cambridge: Polity. Habermas, J (1987). The Theory of Communicative Action, Vol II. Cambridge: Polity.

Krugman, P (1994). Peddling Prosperity: Economic sense and nonsense in the age of diminished expectations. New York, NY: Norton.

Larsson, M (2010). Noko Jeans. Vice Style. , (p. 11). http://vicestyle.com/en/features/ articles/item/Noko-Jeans. Accessed 28 May 2012.

Lazzarato, M (2004). From capital-labour to capital-life. Ephemera, 4(3), 187-208.

Lazzarato, M (2007). Strategies of the political entrepreneur. SubStance, 36(1).

Mintzberg, H, Ahlstrand, B, \& Lampel, J (1998). Strategy Safari. London: FT Prentice Hall.

Palmås, K (2011). Predicting what you'll do tomorrow: Panspectric surveillance and the contemporary corporation. Surveillance \& Society, 8(3), 338-354.

Ries, E (2011). The Lean Startup: How today's entrepreneurs use continuous innovation to create radically successful businesses. New York, NY: Crown Publishing Group.

Schumpeter, JA (1943). Capitalism, Socialism and Democracy. London: Allen \& Unwin.

von Hippel, E (2005). Democratizing Innovation. Cambridge, MA: MIT Press.

Weber, M (1970). Politics as a vocation. In H. Gerth \& C. W. Mills (Eds.), From Max Weber: Essays in Sociology. London: Routledge.

Wieners, B (1996). Color him a provocateur. Wired, 4(12), 258-259.

doi:10.1186/2192-5372-1-5

Cite this article as: Palmås: Lazzarato's 'political entrepreneur' revisited: the case of Noko Jeans. Journal of Innovation and Entrepreneurship 2012 $1: 5$.

\section{Submit your manuscript to a SpringerOpen ${ }^{\circ}$ journal and benefit from:}

- Convenient online submission

- Rigorous peer review

- Immediate publication on acceptance

- Open access: articles freely available online

- High visibility within the field

- Retaining the copyright to your article

Submit your next manuscript at $>$ springeropen.com 